\title{
PENGARUH BUDAYA ORGANISASI, MOTIVASI KERJA DAN DISIPLIN KERJA TERHADAP KINERJA GURU SMA NEGERI DI KOTA MAKASSAR
}

\author{
Ratno Nur Suryadi \\ Program Pascasarjana, Universitas Negeri Makassar \\ e-mail: ratno.nur93@gmail.com
}

\begin{abstract}
Education is the basic capital to create superior human resources. The main educational world is the school. The teacher is one of the human resources in the school. There are many factors that influence teachers' performances: principal of leadership, organizational culture, compensation, motivation, discipline and others. The purpose of this research was (i) to know the influence of organizational culture on the performance of economy teacher of SMA Negeri in Makassar City (ii) to know the influence of work motivation on economy teachers' performance of SMA Negeri in Makassar City (iii) to know influence of work discipline to economy teachers' performance SMA Negeri in Makassar City (iv) to know the influence of organizational culture, work motivation and work discipline on the performance of economy teacher of SMA Negeri in Makassar City. This research was quantitative research with the sample using saturated sample that is all economy teacher of SMA Negeri in Makassar city as many as 60 people.

The results showed that (i) the partial variable of organizational culture, work motivation, and work discipline have a significant effect on economy teachers' performance SMA Negeri in Makassar City (ii) simultaneously organizational culture variable, work motivation, and work discipline have a significant effect on economy teachers' performance SMA Negeri in Makassar City.
\end{abstract}

\begin{abstract}
Abstrak
Pendidikan adalah modal dasar untuk menciptakan SDM yang unggul. Dunia pendidikan yang utama adalah sekolah. Guru merupakan salah satu SDM yang berada di sekolah. Terdapat banyak faktor yang mempengaruhi kinerja guru yaitu kepemimpinan kepala sekolah, budaya organisasi, kompensasi, motivasi, kedisiplinan dan lain lain. Tujuan dari penelitian ini adalah (i) untuk mengetahui pengaruh budaya organisasi terhadap kinerja guru ekonomi SMA Negeri di Kota Makassar (ii) Untuk mengetahui pengaruh motivasi kerja terhadap kinerja guru ekonomi SMA Negeri di Kota Makassar (iii) untuk mengetahui pengaruh disiplin kerja terhadap kinerja guru ekonomi SMA Negeri di Kota Makassar (iv) untuk mengetahui pengaruh budaya organisasi, motivasi kerja dan disiplin kerja terhadap kinerja guru ekonomi SMA Negeri di Kota Makassar. Penelitian ini adalah penelitian kuantitatif dengan pengambilan sampel menggunakan sampel jenuh yaitu seluruh guru ekonomi SMA Negeri di Kota Makassar sebanyak 60 orang.

Hasil penelitian menunjukkan bahwa (i) secara parsial variabel budaya organisasi, motivasi kerja, dan disiplin kerja berpengaruh signifikan terhadap kinerja guru ekonomi SMA Negeri di Kota Makassar (ii) secara simultan variabel budaya organisasi, motivasi kerja, dan disiplin kerja berpengaruh yang signifikan terhadap kinerja guru ekonomi SMA Negeri di Kota Makassar.
\end{abstract}

Keyword : Organizational Culture, Work Motivation, Work Discipline, and Teachers' Performance

This is an open access article distributed under the Creative Commons Attribution License, which permits unrestricted use, distribution, and reproduction in any medium, provided the original work is properly cited. (C2020 by author. 


\section{Introduction}

Pendidikan merupakan salah satu upaya untuk membangun dan meningkatkan mutu sumber daya manusia menuju era globalisasi yang penuh dengan tantangan. Jadi disadari bahwa pendidikan merupakan sesuatu yang sangat fundamental bagi setiap individu karena pendidikan sangat penting untuk menjamin perkembangan dan kelangsungan kehidupan bangsa.

Pendidikan mempunyai peranan yang sangat penting dalam keseluruhan aspek manusia. $\mathrm{Hal}$ ini disebabkan pendidikan berpengaruh terhadap perkembangan manusia, yakni pada keseluruhan aspek kepribadian manusia. Berbeda dengan bidang-bidang lain, seperti arsitektur, ekonomi dan sebagainya, yang berperan menciptakan sarana dan prasarana bagi kepentingan manusia. Pendidikan lebih terkait langsung dengan pembentukan manusia, dalam hal ini pendidikan menentukan model manusia yang akan dihasilkannya. Keberhasilan pendidikan manusia tidak dapat lepas dari lingkungan sebagai realitas sosial.

Upaya meningkatan kualitas pendidikan di sekolah pada dasarnya terjadi jika peningkatan kinerja guru terjadi secara optimal, kualitas guru akan tercermin dalam proses belajar mengajar yang terlaksana sesuai dengan tuntutan kurikulum. Undang-undang Nomor 14 Tahun 2005 tentang Guru dan Dosen, Pasal 1 Ayat 1 mengamanatkan bahwa tugas utama guru yang dimaksud adalah mendidik, mengajar, membimbing, mengarahkan, melatih, menilai, dan mengevaluasi peserta didik pada pendidikan anak usia dini jalur pendidikan baik itu formal, pendidikan dasar, dan pendidikan menengah serta tugas tambahan yang relevan dengan fungsi sekolah.

Selanjutnya, Pasal 31 Undang-Undang Dasar Negara Republik Indonesia Tahun 1945 mengamanatkan bahwa (1) Setiap warga Negara berhak mendapat pendidikan; (2) Setiap warga negara wajib mengikuti pendidikan dasar dan pemerintah wajib membiayainya; (3) Pemerintah mengusahakan dan menyelenggarakan satu sistem pendidikan nasional, yang meningkatkan keimanan dan ketaqwaan serta ahlak mulia dalam rangka mencerdaskan kehidupan bangsa, yang diatur dengan Undang-Undang; (4) Negara memprioritaskan anggaran pendidikan sekurang-kurangnya 20 persen dari anggaran pendapatan dan belanja negara serta dari anggaran pendapatan dan belanja daerah untuk memenuhi kebutuhan penyelenggeraan pendidikan nasional; dan (5) Pemerintah memajukan ilmu pengetahuan dan teknologi dengan menjunjung tinggi nilai agama dan persatuan bangsa untuk kemajuan peradaban serta kesejahteraan umat manusia.

Salah satu amanat Undang-Undang Dasar Negara Republik Indonesia Tahun 1945 tersebut kemudian diatur lebih lanjut dalam Undang-Undang Nomor 20 Tahun 2003 tentang Sistem Pendidikan Nasional, yang memiliki visi terwujudnya sistem pendidikan sebagai pranata sosial yang kuat dan berwibawa untuk memberdayakan semua warga Negara Indonesia berkembang menjadi manusia yang berkualitas sehingga mampu dan proaktif menjawab tantangan zaman yang selalu berubah. Sumber daya manusia (SDM) unggul merupakan persyaratan utama bagi terwujudnya bangsa dan negara yang maju. Berapapun besar sumber daya alam (SDA), modal sarana prasarana yang tersedia, pada akhirnya di tangan sumber daya manusia (SDM) yang handal sajalah target pembangunan bangsa dan negara dapat dicapai. Dalam perspektif berpikir seperti ini, suatu bangsa tak dapat mencapai kemajuan tanpa adanya suatu sistem pendidikan yang baik.

Pendidikan adalah modal dasar untuk menciptakan sumber daya manusia (SDM) yang unggul. Dunia pendidikan yang utama adalah sekolah. Sekolah merupakan salah satu lembaga alternatif pelayanan pendidikan. Sekolah sebagai suatu lembaga tentunya memiliki visi, misi, tujuan dan fungsi. Untuk mengemban misi, mewujudkan visi, mencapai tujuan, dan menjalankan fungsinya sekolah memerlukan tenaga profesional, tata kerja organisasi dan sumber-sumber yang mendukung baik finansial maupun non finansial.

Guru merupakan salah satu sumber daya manusia (SDM) yang berada di sekolah. Kinerja guru di sekolah mempunyai peran penting dalam pencapaian tujuan sekolah. Masalah kinerja menjadi sorotan berbagai pihak, kinerja pemerintah akan dirasakan oleh masyarakat dan kinerja guru akan dirasakan oleh siswa atau orang tua siswa. Kinerja guru sangat penting untuk megetahui kemampuan, keterampilan, kualitas kerja, kuantitas kerja dan waktu yang digunakan guru dalam bekerja. Kinerja seorang guru dikatakan baik apabila guru tersebut mampu 
menguasai dan mengembangkan bahan pelajaran, kreatif dalam penyampaian pembelajaran, mampu menunjukkan komitmen yang tinggi pada tugas mengajar, disiplin dalam pekerjaan, melakukan kerjasama dengan semua warga sekolah, serta memiliki kepribadian yang menjadi panutan bagi siswa.

Kinerja guru yang maksimal juga diharapkan oleh semua pihak sekolah agar mampu memberikan kontribusi yang maksimal sehingga hasil yang akan dicapai memuaskan. Ketika guru mampu melaksanakan tugas dengan baik dan dilaksanakan secara tepat waktu dapat berpengaruh pada keberlangsungan proses belajar mengajar. Kinerja guru juga dipengaruhi oleh berbagai faktor diantaranya adalah kepemimpinan kepala sekolah, budaya organisasi, kompensasi, motivasi, kedisiplinan dan lain lain. Namun pada penelitian ini, hanya akan meneliti kinerja guru yang dipengaruhi oleh motivasi kerja, disiplin kerja dan budaya organisasi

Keberhasilan prestasi sekolah ditentukan oleh berbagai faktor, diantaranya motivasi kerja seorang guru. Seorang guru dapat bekerja secara professional jika pada dirinya terdapat motivasi yang tinggi. Guru yang memiliki motivasi yang tinggi biasanya akan melaksanakan tugasnya dengan penuh semangat dan energik, karena ada motif-motif atau tujuan tertentu yang melatarbelakangi tindakan tersebut. Motif itulah sebagai faktor pendorong yang memberi kekuatan kepadanya, sehingga ia mau dan rela bekerja keras. Motivasi kerja merupakan salah satu faktor yang ikut menentukan tinggi rendahnya kinerja seorang guru. Tanpa adanya motivasi kerja, keahlian atau usaha bekerja dari seorang guru tidak akan meningkatkan prestasi kerja. Selain itu juga jika motivasi untuk bekerja tidak disertai dengan keahlian untuk bekerja maka tidak akan meningkatkan prestasi kerja.

Motivasi itu timbul tidak saja karena ada unsur di dalam dirinya tetapi juga karena adanya stimulus dari luar. Seberapa pun tingkat kemampuan yang dimiliki seseorang mereka pasti butuh motivasi. Dengan perkataan lain potensi sumber daya manusia adalah sesuatu yang terbatas. Kinerja seseorang dengan demikian merupakan fungsi dari faktor-faktor kemampuan dan motivasi dirinya (Mangkuprawira, 2007). Motivasi kerja perlu dipelihara dengan baik. Sekolah yang baik harus mengetahui faktor penggerak apakah yang memicu guru termotivasi dalam melakukan pekerjaan. Seorang guru yang termotivasi biasanya bersifat energik dan bersemangat dalam mengerjakan sesuatu secara konsisten dan aktif mencari peran dengan tanggung jawab yang lebih besar, guru tidak akan merasa takut dihadapkan pada tantangan, bahkan justru termotivasi untuk mengatasinya.

Setiap guru mempunyai motivasi yang berbeda. Seorang guru yang memiliki motivasi kerja yang tinggi akan memiliki kemauan keras atau kesungguhan hati untuk mengerjakan tugastugasnya, sehingga kinerjanya meningkat. Sebaliknya seorang guru yang memiliki motivasi kerja yang rendah tidak akan memiliki kemauan yang keras untuk mengerjakan tugas-tugasnya dan akibatnya kinerjanya akan menurun

Kedisiplinan sangat penting dalam proses pembelajaran, tanpa disiplin yang baik, suasana sekolah kurang kondusif, secara positif disiplin memberi dukungan lingkungan yang tenang dan tertib bagi proses pembelajaran. Menurut Sastrohadiwiryo $(2005 ; 291)$ disiplin kerja adalah sebagai suatu sikap menghormati, menghargai, patuh dan taat terhadap peraturan peraturan yang berlaku, baik yang tertulis maupun yang tidak tertulis serta sangggup menjalankannnya dan tidak mengelak untuk menerima sanksi-sanksi apabila ia melanggar tugas dan wewenang yang diberikan kepadanya. Dengan demikian disiplin merupakan sikap untuk mematuhi dan mentaati semua peraturan organisasi dalam melakukan pekerjaan untuk mencapai tujuan yang diharapkan. Disiplin berkaitan dengan adanya aturan atau tata tertib. Sehingga guru yang disiplin dapat diartikan sebagai guru yang menaati semua peraturanperaturan yang telah ditetapkan organisasi dan norma sosial yang berlaku. Disiplin yang baik mencerminkan besarnya rasa tanggung jawab seseorang terhadap tugas-tugas yang diberikan kepadanya. Dengan disiplin dapat mendorong gairah kerja, semangat kerja, dan mendukung terwujudnya tujuan yang telah direncanakan. Disiplin yang tinggi akan mampu membangun kinerja yang profesional, karena pemahaman disiplin yang baik guru mampu mencermati aturan-aturan dan langkah strategis dalam melaksanakan proses kegiatan belajar mengajar. Kedisiplinan bagi guru merupakan bagaian tak terpisahkan dalam melaksanakan tugas dan kewajibannya. 
Selain dipengaruhi oleh faktor-fakor di atas kinerja guru juga dapat dipengaruhi oleh budaya atau kultur organisasi sekolah. Budaya atau kultur organisasi merupakan kesepakatan bersama tentang nilai yang dianut bersama dalam kehidupan organisasi dan mengikat semua organisasi yang bersangkutan. Budaya inilah yang nantinya akan berperan dalam menentukan struktur dan berbagai sistem operasional yang menghasilkan norma-norma, peraturan-peraturan, dan bagaimana interaksi didalam sebuah organisasi. Budaya organisasi di lingkungan sekolah juga memberikan dampak bagi kinerja guru, dimana budaya organisasi tersebut sangat erat kaitannya dalam meningkatkan kinerja guru, sebab dengan terciptanya budaya organisasi yang baik serta ditunjang oleh adanya kerja sama dengan sesama guru, maka akan dapat dicapai hasil yang dapat meningkatkan kinerja guru. Dengan dicapainya tingkat kinerja yang baik maka harapan untuk menjadikan mutu sekolah lebih baik akan dapat dicapai. Kinerja guru akan dapat meningkat dalam proses pembelajaran di dalam kelas.

Berdasarkan hasil studi pendahuluan atau temuan yang dilakukan melalui kunjungan kebeberapa SMA Negeri di Kota Makassar, baik melalui pengamatan maupun wawancara dengan beberapa guru terlihat bahwa masih ada beberapa guru yang kinerjanya masih rendah. Hal ini dapat dilihat dari fenomena yang muncul dilapangan yaitu beberapa guru belum mampu menyusun perangkat pembelajaran. Selain itu beberapa guru jumlah jam mengajarnya belum memenuhi jam wajib, yaitu 24 jam. Lebih lanjut dijelaskan bahwa ada guru yang kehadiran untuk mengajar tidak mencapai target sebagaimana tertera dalam kurikulum. Hal ini terlihat bahwa masih ada beberapa guru yang terlambat datang kesekolah melaksanakan tugasnya, tidak masuk mengajar, ada urusan keluarga misalnya pesta. Disamping itu, guru kurang kreatif dalam menciptakan suasana belajar yang menarik dan nyaman. Guru kurang menjalin kerja sama yang baik dengan rekan guru untuk mendiskusikan cara mengajarkan materi tertentu, penggunaan alat peraga masih terlihat sangat kurang, masih adanya ketidakpuasan guru berkenaan dengan pekerjaan dan kebijakan organisasi sekolah, bakat dan minat serta sikap guru dengan pekerjaan kurang prefesional, masih ada guru dalam melaksanakan tugasnya belum sepenuhnya mengacu kepada pengembangan nilai dan sifat-sifat pribadi, masih dirasakan budaya organisasi kurang mendukung pengembangan diri guru, pengaharapan yang terlalu tinggi sehingga tidak sesuai dengan realitas,. Selanjutnya masih ditemukannya guru yang meninggalkan kelas lalu bercerita di kantor atau di kantin sementara siswa di kelas ribut dan tidak belajar. Bahkan masih ada guru yang tidak mengoreksi hasil pekerjaan siswanya. Mereka hanya mengumpulkan pekerjaan siswa dan menumpuknya di kantor atau dibawa pulang ke rumah dan tidak mengembalikannya kepada siswa. Untuk menentukan nilai siswa didasarkan pada pengalaman guru dikelas. Keadaan ini terus berkembang dan mempengaruhi keberhasilan tugas guru secara keseluruhan. Jika dicermati lebih mendalam, motivasi kerja guru erat kaitannya dengan budaya organisasi, dan disiplin kerja untuk meningkatkan kinerja sesuai dengan tugas dan tanggung jawabnya masing-masing.

Kajian penelitian mengenai pengaruh budaya organisasi, motivasi kerja dan disiplin kerja terhadap kinerja guru ekonomi SMA Negeri Se-Kota Makassar. Dalam upaya pengembangan mutu pendidikan yang terus dilakukan sebagai antisipasi dan respons terhadap perkembangan ilmu pengetahuan dan teknologi yang begitu pesat karena hal ini merupakan keharusan dan tanggung jawab lembaga pendidikan. Upaya pengembangan peningkatan mutu pendidikan yang tengah dilakukan antara lain peningkatan mutu pendidik dan tenaga pendidik. Berdasarkan latar belakang tersebut, maka penulis tertarik untuk mengadakan penelitian tesis ini dengan judul "Pengaruh Budaya Organisasi, Motivasi Kerja dan Disiplin Kerja Terhadap Kinerja Guru Ekonomi SMA Negeri di Kota Makassar". Untuk itu tujuan penelitian ini adalah

1. Untuk mengetahui pengaruh budaya organisasi terhadap kinerja guru ekonomi SMA Negeri di Kota Makassar.

2. Untuk mengetahui pengaruh motivasi kerja terhadap kinerja guru ekonomi SMA Negeri di Kota Makassar.

3. Untuk mengetahui pengaruh disiplin kerja terhadap kinerja guru ekonomi SMA Negeri di Kota Makassar. 
4. Untuk mengetahui pengaruh budaya organisasi, motivasi kerja dan disiplin kerja terhadap kinerja guru ekonomi SMA Negeri di Kota Makassar

\section{Method}

Penelitian ini merupakan penelitian kuantitatif dengan metode explonatory research yaitu penelitian yang bertujuan untuk menganalisis hubungan-hubungan antara satu variabel dengan variabel lainnya atau bagaimana suatu variabel mempengaruhi variabel lainnya.

Populasi dalam penelitian ini adalah seluruh guru ekonomi SMA Negeri di Kota Makassar baik yang berstatus PNS, guru bantu maupun guru tidak tetap yakni berjumlah 60 guru (Sumber: Dinas Pendidikan dan Kebudayaan Kota Makassar, 2016). Sedangkan sampel dalam penelitian ini adalah seluruh populasi penelitian.

Tabel Daftar jumlah guru ekonomi SMA Negeri di Kota Makassar (Desember 2016)

\begin{tabular}{|c|c|c|c|c|}
\hline No & Nama Sekolah & Guru PNS & Guru Non PNS & Jumlah \\
\hline 1 & SMAN 1 Makassar & 2 & 0 & 2 \\
\hline 2 & SMAN 2 Makassar & 3 & 0 & 3 \\
\hline 3 & SMAN 3 Makassar & 1 & 1 & 2 \\
\hline 4 & SMAN 4 Makassar & 2 & 0 & 2 \\
\hline 5 & SMAN 5 Makassar & 4 & 0 & 4 \\
\hline 6 & SMAN 6 Makassar & 2 & 0 & 2 \\
\hline 7 & SMAN 7 Makassar & 2 & 1 & 3 \\
\hline 8 & SMAN 8 Makassar & 1 & 0 & 1 \\
\hline 9 & SMAN 9 Makassar & 3 & 0 & 3 \\
\hline 10 & SMAN 10 Makassar & 3 & 0 & 3 \\
\hline 11 & SMAN 11 Makassar & 2 & 2 & 4 \\
\hline 12 & SMAN 12 Makassar & 3 & 0 & 3 \\
\hline 13 & SMAN 13 Makassar & 3 & 0 & 3 \\
\hline 14 & SMAN 14 Makassar & 4 & 0 & 4 \\
\hline 15 & SMAN 15 Makassar & 2 & 0 & 2 \\
\hline 16 & SMAN 16 Makassar & 2 & 0 & 2 \\
\hline 17 & SMAN 17 Makassar & 2 & 0 & 2 \\
\hline 18 & SMAN 18 Makassar & 4 & 0 & 4 \\
\hline 19 & SMAN 19 Makassar & 2 & 0 & 2 \\
\hline 20 & SMAN 20 Makassar & 2 & 0 & 2 \\
\hline 21 & SMAN 21 Makassar & 5 & 0 & 5 \\
\hline
\end{tabular}




\begin{tabular}{cccc}
22 & 2 & 0 & 2 \\
\hline Jumlah & 56 & 4 & 60
\end{tabular}

Sumber : Dinas Pendidikan dan Kebudayaan Kota Makassar, 2016

Penelitian ini menggunakan tiga variabel bebas (variabel independen) dan satu variabel terikat (variabel dependen). Variabel Bebas (variabel independen) dalam penelitian ini adalah budaya organisasi, motivasi kerja dan disiplin kerja. Budaya organisasi merupakan bagaimana perilaku/kebiasaan atau pola kerja yang dilaksanakan oleh guru ekonomi di sekolahnya. Variabel budaya organisasi, diukur dengan menggunakan indicator - indikator yaitu : 1) Individual Autonomy; 2) Structure; 3) Performance Reward; 4) Management Support; 5) Identity; 6) Conflic Tolerance; 7) Risk Tolerance. Motivasi kerja merupakan bagaimana seorang guru terdorong dalam melaksanakan tugasnya sehingga mendukung dan memungkinkan untuk berlangsungnya proses belajar. Variabel motivasi kerja, diukur dengan menggunakan indikator indikator yaitu 1) kebutuhan akan kekuasaan (Need For Power), 2) kebutuhan akan afiliasi (Need For Affiliation), dan 3) kebutuhan akan prestasi (Need For Achievement). Disiplin kerja adalah bagaimana kemampuan kerja seorang guru untuk secara teratur, dan bekerja sesuai dengan aturan-aturan yang berlaku dengan tidak melanggar aturan-aturan yang sudah ditetapkan didalam lingkungan sekolah. Variabel disiplin kerja, diukur melalui indikator - indikator yaitu 1) Kualitas kedisiplinan kerja; 2) Kuantitas pekerjaan; 3) Kompensasi; 4) Lokasi tempat kerja atau tempat tinggal; 5) Konservasi.

Variabel terikat (dependen) dalam penelitian ini adalah kinerja guru ekonomi SMA Negeri di Kota MakassarKinerja guru suatu kegiatan yang dilakukan oleh seorang guru untuk melaksanakan tugas dan tanggung jawab sesuai dengan harapan dan tujuan yang telah ditetapkan, dan sebagai hasil evaluasi terhadap pekerjaan yang dilakukan dibandingkan dengan kriteria atau standar yang telah ditetapkan. Variabel kinerja guru, diukur melalui indikatorindikator yaitu 1) kualitas kerja, 2) kecepatan dan ketepatan kerja, 3) inisiatif kerja, 4) kemampuan kerja, dan 5) komunikasi kerja.

Metode pengumpulan data merupakan merupakan sesuatu yang sangat penting dalam penelitian, karena tujuan utama dari penelitian adalah mendapatkan data. Adapun metode pengumpulan data yang dipergunakan dalam penelitian ini adalah sebagai berikut: kuesioner, Wawancara dan Dokumentasi

Analisis data merupakan tahapan yang kritis dalam proses penelitian yang bertujuan menyediakan informasi untuk memecahkan masalah. Adapun teknik analisis data yang digunakan dalam penelitian ini adalah sebagi berikut: Uji Asumsi Klasik ( uji normalitas, uji multikolinearitas, dan uji heterokedastisitas), Analisis Regresi Linear Berganda, dan Uji Hipotesis (uji simultan, uji parsial, dan koefisien determinasi)

\section{Results and Discussions}

\section{A. Hasil}

\section{Gambaran Umum Lokasi Penelitian}

Kota Makassar merupakan kota metropolitan terbesar di kawasan Indonesia Timur yang berada tepatnya di pesisir barat daya Pulau Sulawesi dan berbatasan dengan Selat Makassar di sebelah barat, Kabupaten Kepulauan Pangkajene di sebelah utara, Kabupaten Maros di sebelah timur dan Kabupaten Gowa di sebelah selatan. Dengan memiliki wilayah seluas 199,26 km² dan jumlah penduduk lebih dari 1,6 juta jiwa, kota ini berada di urutan kelima berpenduduk terbesar di Indonesia setelah Jakarta, Surabaya, Bandung, Medan.

Berdasarkan Peraturan Daerah Kota Makassar Nomor 3 Tahun 2015 Kota Makassar dibagi atas 15 kecamatan dan 153 kelurahan yaitu Kecamatan Biringkanaya, Kecamatan Bontoala, Kecamatan Mariso, Kecamatan Mamajang, Kecamatan Makassar, Kecamatan 
Manggala, Kecamatan Panakkukang, Kecamatan Rappocini, Kecamatan Tamalate, Kecamatan Tamalanrea, Kecamatan Tallo, Kecamatan Ujung Pandang, Kecamatan Ujung Tanah, Kecamatan Wajo dan Kecamatan Kepulauan Sangkarrang.

Didalam bidang pendidikan, Pemerintah Kota Makassar menciptakan program dalam bidang pendidikan yang diberi nama 18 Revolusi Pendidikan. 18 Perintah Revolusi Pendidikan dirancang sebagai master plan pendidikan Kota Makassar yang mengakomodir ketiga lingkungan utama pendidikan yaitu pendidikan dirumah, pendidikan disekolah dan pendidikan di lingkungan sosial. Tujuan program ini adalah untuk mengasah kecerdasan intelektual, emosional, spiritual, serta sebagai upaya untuk mendekatkan anak-anak Makassar pada akar budayanya. Adapun 18 Revolusi Pendidikan meliputi : 1) Semua anak bisa sekolah, 2) Semua Adiwiyata, 3) Semua bebas Narkoba, Psikotoprika dan Zat Adiktif lainnya, 4) Sekolah 9 tahun, 5) 100 Sekolah Bintang lima, 6) Satu sekolah 1 Smart Library, 7) Satu sekolah 2 guru innovator, 8) Satu Sekolah 5 Super Students, 9) Satu Sekolah 2 Smart Class, 10) Satu Sekolah 1 Super Inovasi, 11) Satu Sekolah 5 Gang Debat, 12) Satu Anak 1 Tari, 13) Satu Anak 1 Bakat, 14) Satu Anak 1 Olah Raga, 15) Satu Anak 3 Tanaman, 16) Festival Bakat, 17) Olimpiade Sekolah dan 18) Liga Debat. Didalam penyelenggarakan pendidikan di Kota Makassar tahun 2014 - 2019 menetapkan prinsip didasarkan dengan norma agama dan kearifan lokal dalam pelayanan menjadi suatu motto yaitu : SMART (Senyum, Menyapa, Akuntabel, Ramah, Terpercaya). Adapun Visi dan Misi Dinas Pendidikan Kota Makassar yaitu:

a. Visi : Mewujudkan Pendidikan Yang Berwawasan Global, Inovatif, Berkarakter dan Religius.

b. Misi : Menyediakan deposito pendidikan gratis bagi siswa dari keluarga prasejahtera, Menjamin Kesetaraan dan Ketersediaan akses layanan pendidikan yang bermutu dan terjangkau, Meningkatkan kualitas proses pembelajaran berbasis e-learning yang merujuk pada perkembangan global, Meningkatkan kompetensi tenaga tenaga pendidik untuk menjamin relevansi iuran pendidikan dengan kebutuhan masyarakat, Menjamin keterlaksanaan Program Pendidikan Universal dan Program Pendidikan Orang Dewasa (Melek Huruf), Menjamin keterlaksanaan kurikulum yang holistik berlandaskan nilai-nilai keagamaan, moral dan karakter bangsa, Mewujudkan kelestarian dan memperkukuh kebudayaan lokal dan Menjamin peyelenggaraan pendidikan yang transparan dan akuntabel.

\section{Uji Instrument Penelitian}

\section{a. Uji Validitas}

Uji validitas dilakukan dengan membandingkan $r_{\text {hitung }}$ dengan $r_{\text {tabel }}$ untuk degree of freedom (df) $=\mathrm{n}-2$ dalam hal ini $\mathrm{n}$ adalah jumlah sampel. Besar derajat kebebasan atau $\mathrm{df}=60-4$ maka didapat angka 56, dan alpha 0,05 maka nilai $r_{\text {tabel }}=0,2586$. Jika $r_{\text {hitung }}$ lebih besar dari $r_{\text {tabel }}$, dan nilai signifikan lebih kecil $<0,05$, maka butir pertanyaan dinyatakan valid. Dari 60 item pertanyaan yang terdiri dari 18 pertanyaan X1, 15 pertanyaan X2 dan 12 pertanyaan X3 dan 20 pertanyaan $\mathrm{Y}$, semunnya valid.

\section{b. Uji Reliabilitas}

Hasil uji relialibilitas menunjukkan bahwa setiap nilai Cronbach Alpha dari masing-masing varibel lebih besar dibandingkan dengan standar Cronbach Alpha yaitu 0,6. Hal ini menunjukkan bahwa seluruh indkator dari setiap variabel dalam penelitian dinyatakan relibel dan instrumen penelitian tersebut dapat digunakan lebih dari satu kali dengan menggunakan variabel penelitian yang sama.

\section{Uji Asumsi Klasik}

\section{a. Uji Normalitas}


Uji normalitas bertujuan untuk menguji apakah dalam model regresi, variabel bebas dan variabel terikat, keduanya terdistribusikan secara normal ataukah tidak. Uji normalitas data dalam penelitian ini dapat dilihat dengan menggunakan uji Kolmogorof-Smirnof satu sample (One sample Kolmogorof-Smirnof test). Hasil pengujian yang dimaksud dapat ditabulasikan dalam tabel sebagai berikut:

Tabel Uji Normalitas dengan Kolmogorof-Smirnof satu sample (One sample Kolmogorof-Smirnof test)

\begin{tabular}{|c|c|c|}
\hline \multicolumn{3}{|c|}{ One-Sample Kolmogorov-Smirnov Test } \\
\hline & & $\begin{array}{l}\text { Unstandardiz } \\
\text { ed Residual }\end{array}$ \\
\hline$N$ & & 60 \\
\hline Normal Parameters ${ }^{a, b}$ & Mean & $0 \mathrm{E}-7$ \\
\hline & Std. Deviation & 3.59263897 \\
\hline Most Extreme Differences & Absolute & .045 \\
\hline & Positive & .045 \\
\hline & Negative & -.038 \\
\hline Kolmogorov-Smirnov Z & & .352 \\
\hline Asymp. Sig. (2-tailed) & & 1.000 \\
\hline
\end{tabular}

Tabel diatas menunjukkan nilai Asymp.Signifikan variabel di atas adalah 1 lebih besar dari 0,05. Maka data dapat dikatakan normal dan dapat digunakan untuk perhitungan statistik parametrik. Jadi kita dapat menyimpulkan bahwa, karena data pada variabel-variabel penelitian ini terdistribusi normal maka sampel yang diambil sebagai responden dianggap dapat mewakili keadaan dari populasi.

\section{b. Uji Multikolonieritas}

Pengujian multikolinieritas bertujuan untuk mengetahui hubungan yang sempurna antar variabel bebas dalam model regresi. Gejala multikolinieritas dapat dilihat dari nilai tolerance dan nilai Varian Inflation Factor (VIF). Bila nilai VIF lebih kecil dari 10 dan nilai toleransinya di atas 0,1 atau $10 \%$ maka dapat disimpulkan bahwa model regresi tersebut tidak terjadi multikolinieritas.

Tabel Hasil Uji Multikolinieritas

Coefficients $^{\mathrm{a}}$

\begin{tabular}{|ll|r|l|}
\hline \multirow{2}{*}{ Model } & \multicolumn{2}{|c|}{ Collinearity Statistics } \\
\cline { 3 - 4 } & & Tolerance & \multicolumn{1}{c|}{ VIF } \\
\hline 1 & Budaya Organsasi & .462 & 2.163 \\
& Motivasi Kerja & .346 & 2.892 \\
& Disiplin Kerja & .610 & 1.640 \\
\hline
\end{tabular}

a. Dependent Variable: Kinerja Guru

Berdasarkan dari tabel di atas dapat dilihat bahwa nilai Tolerance masing-masing variabel pada penelitian ini lebih besar dari 0,05 ( Tolerance $>0,05$ ) dan nilai dari VIF masingmasing variabel lebih kecil dari $10(\mathrm{VIF}<10)$, dengan begitu dapat kita simpulkan bahwa tidak terjadi multikolinearitas antara variabel bebas (X) dalam penelitian ini.

\section{c. Uji Heterosidastisitas}

Uji ini bertujuan untuk menguji apakah dalam sebuah model regresi terjadi ketidaksamaan varians dari residual, dari satu pengamatan ke pengamatan yang lain. Jika 
varians dari residual dari satu pengamatan ke pengamatan yang lain tetap, maka disebut homoskedastisitas dan jika varians berbeda, disebut heterokedastisitas

Tabel Hasil Uji Heterosidastisitas

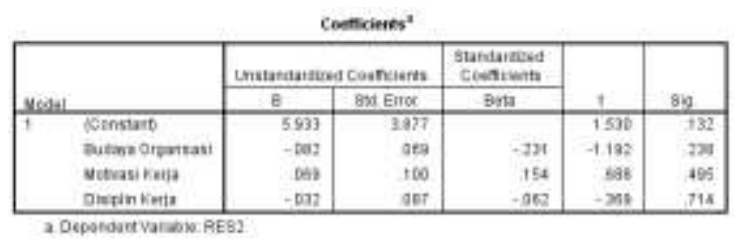

Berdasarkan hasil uji heteroskedastisitas diketahui bahwa nilai signifikansi Budaya Organisasi (X1) sebesar 0,238, Motivasi Kerja (X2) sebesar 0,495, Disiplin Kerja (X3) sebesar 0,714, Karena nilai signifikansinya tidak ada yang lebih dari 0,05 maka dapat disimpulkan bahwa tidak terjadi heteroskedastisitas.

\section{Analisis Regresi Berganda}

Analisis regresi berganda digunakan untuk mengukur seberapa besar pengaruh variabel independen, dalam hal ini Budaya Organisasi (X1), Motivasi Kerja (X2) dan Disiplin Kerja terhadap variabel dependen atau Kinerja Guru (Y). Dalam penelitian ini analisis regresi berganda di uji dengan menggunakan analisis SPSS for windows release 20. Untuk lebih jelasnya dapat dilihat pada tabel berikut :

Tabel Hasil Analisis Regresi Berganda

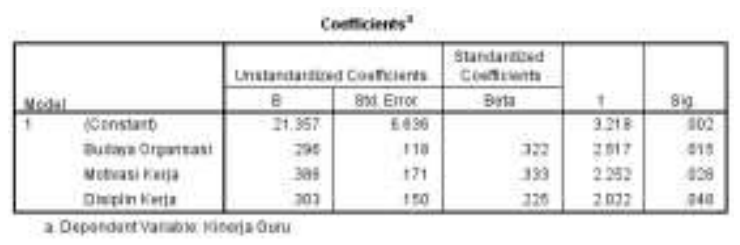

Berdasarkan tabel diatas interpretasi persamaan regresi linier berganda sebagai berikut :

$\mathrm{Y}=\mathrm{a}+\mathrm{b} 1 \mathrm{X} 1+\mathrm{b} 2 \mathrm{X} 2+\mathrm{b} 3 \mathrm{X} 3$

$Y=21,357+0,296 X 1+0,386 X 2+0,303 X 3$

Dari persamaan diatas dapat dijelaskan bahwa ;

a. Nilai Konstanta sebesar 21,357. Hal ini menunjukkan bahwa jika budaya organisasi, motivasi kerja dan disiplin kerja tetap atau tidak mengalami penambahan dan pengurangan, maka kinerja guru sebesar nilai konstanta yaitu 21,357.

b. Nilai koefesien budaya organisasi untuk variabel X1 sebesar 0,296. Hal ini mengandung arti bahwa setiap kenaikan budaya organisasi satu satuan maka variabel kinerja guru (Y) naik sebesar 0,296 dengan asumsi bahwa variabel bebas yang lain dari model regresi adalah tetap.

c. Nilai koefesien motivasi kerja untuk variabel X2 sebesar 0,386. Hal ini mengandung arti bahwa setiap kenaikan motivasi kerja satu satuan maka variabel kinerja guru (Y) naik sebesar 0,386 dengan asumsi bahwa variabel bebas yang lain dari model regresi adalah tetap.

d. Nilai koefesien disiplin kerja untuk variabel X3 sebesar 0,303. Hal ini mengandung arti bahwa setiap kenaikan disiplin kerja satu satuan maka variabel kinerja guru $(\mathrm{Y})$ naik sebesar 0,303 dengan asumsi bahwa variabel bebas yang lain dari model regresi adalah tetap.

\section{Uji Hipotesis}

\section{a. Uji Parsial (Uji T)}


Uji Parsial (Uji T) dilakukan untuk mengetahui apakah masing-masing variabel independen mempunyai pengaruh terhadap variabel dependen. Pengujian dilakukan dengan melihat nilai $\mathrm{T}_{\text {hitung }}$ dan $\mathrm{T}_{\text {tabel, }}$, apabila $\mathrm{T}_{\text {hitung }}>\mathrm{T}_{\text {tabel }}$ maka dapat dikatakan mempunyai pengaruh yang signifikan, dimana hasil selengkapnya dapat diketahui melalui tabel berikut ini

Tabel Hasil Uji Parsial (Uji T)

\begin{tabular}{lcc}
\hline \multicolumn{3}{c}{ Coefficients $^{\mathbf{a}}$} \\
\hline \multicolumn{1}{c}{ Model } & $\mathbf{t}_{\text {hitung }}$ & Sig \\
\hline $\begin{array}{l}\text { Budaya Organisasi } \\
\text { (X1) }\end{array}$ & 2,517 & 0,015 \\
Motivasi Kerja (X2) & 2,252 & 0,028 \\
Disiplin Kerja (X3) & 2,022 & 0,048 \\
\hline
\end{tabular}

Berdasarkan Data diatas menunjukkan bahwa nilai $\mathrm{T}_{\text {hitung }}$ untuk budaya organisasi terhadap kinerja guru sebesar 2,517 sedangkan untuk nilai $T_{\text {tabel }}$ sebesar 2,003. Karena $T_{\text {hitung }}$ lebih besar dari $\mathrm{T}_{\text {tabel }}$, hal ini menunjukkan bahwa ada pengaruh yang positif dan signifikan antara budaya organisasi terhadap kinerja guru Ekonomi SMA Negeri di Kota Makassar. Nilai $\mathrm{T}_{\text {hitung }}$ untuk motivasi kerja terhadap kinerja guru sebesar 2,252 sedangkan untuk nilai $\mathrm{T}_{\text {tabel }}$ sebesar 2,003. Karena $T_{\text {hitung }}$ lebih besar dari $T_{\text {tabel }}$, hal ini menunjukkan bahwa ada pengaruh yang positif dan signifikan antara motivasi kerja terhadap kinerja guru Ekonomi SMA Negeri di Kota Makassar. Nilai $\mathrm{T}_{\text {hitung }}$ untuk disiplin kerja terhadap kinerja guru sebesar 2,022 sedangkan untuk untuk nilai $\mathrm{T}_{\text {tabel }}$ sebesar 2,003. Karena $\mathrm{T}_{\text {hitung }}$ lebih besar dari $\mathrm{T}_{\text {tabel }}$, hal ini menunjukkan bahwa ada pengaruh yang positif dan signifikan antara disiplin kerja terhadap kinerja guru Ekonomi SMA Negeri di Kota Makassar.

\section{b. Uji Simultan (Uji F)}

Uji $\mathrm{F}$ dilakukan untuk melihat pengaruh variabel bebas secara bersama-sama atau simultan terhadap variabel dependen atau terikat. Uji $\mathrm{F}$ dilakukan dengan membandingkan $\mathrm{F}_{\text {hitung }}$ dan $\mathrm{F}_{\text {tabel. }}$.

Tabel Hasil Uji Simultan (Uji F)

\begin{tabular}{lll}
\hline $\mathrm{F}_{\text {hitung }}$ & $\mathrm{F}_{\text {tabel }}$ & sig \\
\hline $\mathbf{2 5 , 4 6 2}$ & 2,77 & 0,000 \\
\hline
\end{tabular}

Pada tabel tersebut, kita dapa peroleh nilai $\mathrm{F}_{\text {hitung }}=25,462>\mathrm{F}_{\text {tabel }}=2,77$ dengan tingkat signifikansi $0,000<0,05$. Hal ini menandakan bahwa bahwa secara simultan variabel budaya organisasi, motivasi kerja dan disiplin kerja mempunyai pengaruh yang signifikan terhadap kinerja guru SMA Negeri di Kota Makassar.

\section{c. Koefesien Determinasi}

Koefisien determinasi digunakan untuk menguji seberapa besar pengaruh variabel bebas yakni Budaya Organisasi (X1), Motivasi Kerja (X2) dan Disiplin Kerja (X3) terhadap variabel terikat yakni Kinerja Guru (Y) Ekonomi SMA Negeri di Kota Makassar. Hasil selengkapnya dapat diketahui melalui tabel berikut ini;

Tabel Hasil Uji Koefisien Deteriminasi

\section{Model Summary}




\begin{tabular}{ccc}
\hline Model & R Square & $\begin{array}{c}\text { Adjusted R } \\
\text { Square }\end{array}$ \\
\hline 1 & 0,577 & 0,554 \\
\hline
\end{tabular}

Tabel diatas menunjukkan bahwa nilai koefisien determinasi (Adjusted $R$ square) yang diperoleh sebesar 0,554. Hal ini berarti 55,4 persen variasi variabel kinerja guru ekonomi SMA Negeri di Kota Makassar dapat dijelaskan oleh variabel budaya organisasi, motivasi kerja dan disiplin kerja, sedangkan sisanya sebesar $44,6 \%$ diterangkan oleh variabel lain yang tidak disebutkan dalam penelitian ini

\section{PEMBAHASAN}

\section{Pengaruh Budaya Organisasi Terhadap Kinerja Guru Ekonomi SMA Negeri di Kota Makassar}

Berdasarkan hasil penelitian menunjukkan bahwa budaya organisasi memiliki pengaruh positif dan signifikan terhadap kinerja guru ekonomi SMA Negeri di Kota Makassar. Temuan ini juga membuktikan bahwa budaya organisasi yang terdiri dari indikator otonomi individu, struktur, penghargaan kinerja, dukungan manajemen, identitas, toleransi terhadap konflik, toleransi terhadap resiko mempunyai pengaruh positif dan signifikan terhadap kinerja guru.

Fakta ini sesuai dengan filosofi budaya organisasi sebagai pengubah dan pembentuk sikap dan prilaku pegawai untuk tunduk pada aturan dan pedoman yang telah disepakati. Sebagaimana dikemukakan oleh Mangkunegara (2005: 113) yang menyatakan bahwa budaya organisasi adalah seperangkat asumsi atau sistem keyakinan, nilai-nilai, dan norma yang dikembangkan dalam organisasi yang dijadikan pedoman tingkah laku bagi anggota-anggotanya untuk mengatasi masalah adaptasi eksternal dan internal.

Berdasarkan hasil temuan dilapangan terkait dengan budaya organisasi guru ekonommi SMA Negeri di Kota Makassar dapat dilihat dari segi otonomi individu, bahwa inisiatif yang dilakukan oleh guru terhadap bidang pekerjaannya telah mengacu pada tupoksi yang ada. Akan tetapi terdapat beberapa inisiatif yang dilakukan oleh guru tidak dapat direalisasikan oleh sekolah seperti melakukan pengenalan lapangan terkait dengan pelajaran yang diajarkan..

Dalam kaitannya dengan kinerja, peran budaya organisasi juga sangat penting dalam meningkatkan kinerja guru ekonomi. Dalam banyak kajian budaya organisasi mempengaruhi produktivitas, kinerja, komitmen kepercayaan diri dan perilaku etis. Budaya organisasi berpengaruh positif terhadap komitmen organisasi, kepuasan kerja dan kinerja pegawai Pendapat serupa dikemukakan oleh Tika (2006) menyatakan budaya organisasi mempunyai dampak yang berarti dalam kinerja organisasi jangka panjang. Artinya bagi seorang guru dengan adanya pemahaman budaya organisasi akan memberikan kemudahan dalam menyelesaikan permasalahan dalam mengajar sehingga memberikan kontribusi yang baik bagi kinerjanya.

Untuk itu, budaya organisasi sangat berperan dalam meningkatkan kinerja guru. Sebagaimana dijelaskan oleh Robbins (2006) menyatakan bahwa budaya yang kuat sering dikatakan membantu kinerja karena menciptakan suatu motivasi yang luar biasa dalam diri guru, kadang kadang ditegaskan bahwa nilai nilai dalam perilaku yang dianut bersama membuat orang merasa nyaman dalam bekerja untuk sebuah organisasi, rasa komitmen atau loyal selanjutnya dikatakan membuat orang berusaha lebih keras. Budaya yang juga dikatakan membantu kinerja karena memberikan struktur dan kontrol yang dbutuhkan tanpa harus berstandar pada birokrasi formal yang mencekik, yang dapat menekan tumbuhnya motivasi dan inovasi.

Kekuatan budaya organisasi memberi impact pada kinerja juga direkomendasikan oleh Schermerhorn, et al (2011:366) bahwa perbedaan budaya memberi impact utama pada kinerja organisasi dan kualitas kerja. Satu hal penting bagi pimpinan dalam menciptakan dan mengelola 
budaya organisasi menurut Richard Daft (2010 : 79-84) adalah dengan mempertemukan dengan tujuan strtegis diakui oleh berbagai ahli secara signifikan memberi impact bagi kinerja.

Hasil penelitian ini sejalan dengan hasil studi yang dilakukan oleh Nurfarhaty (Sopiah, 2008) yang menyimpulkan bahwa: (1) budaya organisasi mempunyai pengaruh yang erat dengan kinerja karyawan, (2) budaya organisasi yang terdiri dari inovasi dan kepedulian, perilaku pimpinan dan orientasi tim, berpengaruh terhadap kinerja karyawan. Selanjutnya Rivai (2007:432) berpendapat bahwa budaya organisasi sekolah mengacu ke suatu makna bersama yang dianut oleh anggota-anggota yang membedakan organisasi itu dengan organisasi lain. Budaya kuat juga dikatakan membantu kinerja karena memberikan struktur dan kontrol yang dibutuhkan tanpa harus bersandar pada birokrasi formal yang mencekik yang dapat menekan tumbuhnya motivasi dan inovasi (Sudarmanto 2014 : 181). Hal ini bermakna bahwa membangun budaya organisasi yang baik akan membawa dampak postitif terhadap kinerja guru. Selain itu bermakna pula bahwa semakin baiknya budaya organisasi dapat meningkatkan kinerja guru

\section{Pengaruh Motivasi Kerja terhadap Kinerja Guru Ekonomi SMA Negeri di Kota Makassar}

Berdasarkan hasil penelitian menunjukkan bahwa motivasi kerja memiliki pengaruh positif dan signifikan terhadap kinerja guru ekonomi SMA Negeri di Kota Makassar. Hal ini sejlan dengan penelitian yang dilakukan oleh Ika Wisudawaty yang menyimpulkan bahwa terdapat hubungan positif antara motivasi kerja dengan kinerja guru IPS Sekolah Menengah Pertama (SMP) di Kabupaten Enrekang. Dengan demikian seorang guru sangat dituntut untuk dapat meningkatkan motivasi dirinya untuk bekerja, yang akhirnya kinerja meningkat dan hal ini dapat berpengaruh terhadap mutu pendidikan yang dikelolanya.

Hasil penelitian ini juga sependapat dengan dengan Hamzah B.Uno (2008) yang menyatakan bahwa motivasi kerja merupakan salah satu faktor yang turut menentukan kinerja seseorang. Besar atau kecilnya pengaruh motivasi pada kinerja seseorang tergantung pada seberapa banyak intensitas motivasi yang diberikan. Motivasi kerja guru tidak lain adalah suatu proses yang dilakukan untuk menggerakkan guru agar perilaku mereka dapat diarahkan pada upaya-upaya yang nyata untuk mencapai tujuan yang telah ditetapkan.

Motivasi timbul karena adanya kebutuhan yang belum terpenuhi. Motivasi yang timbul akan mendorong seseorang untuk berperilaku yang diarahkan untuk mencapai tujuannya tersebut yaitu memenuhi kebutuhannya yang belum terpenuhi. Kebutuhan yang dimaksud seperti kebutuhan akan prestasi, kebutuhan akan kekuatan, dan kebutuhan akan afiliasi (Hasibuan 2007 : 162). Dengan segala kebutuhan tersebut, seseorang dituntut untuk lebih giat dan aktif dalam bekerja, karena dapat mendorong seseorang bekerja dan selalu berkeinginan untuk melanjutkan usahanya.

Berdasarkan pengamatan peneliti hal yang dapat membuat motivasi guru tinggi diantaranya : ada komunikasi yang baik antara guru dengan sesama rekan kerja yang dibuktikan adanya keakraban diantara mereka karena komunikasi yang baik dengan rekan kerja membuat guru merasa nyaman dalam bekerja, Guru memiliki komitmen yang baik terhadap lembaga misalnya guru mempunyai tugas tambahan yang salah satunya adalah membimbing siswa yang akan mengikuti lomba mata pelajaran maupun lomba non akademik dengan harapan memperoleh juara, ini berarti guru memiliki tanggungjawab untuk mensukseskan visi dan misi sekolah. Guru siap dengan tugas yang diberikan kepala sekolah misalnya mengikuti berbagai kegiatan pendidikan dan pelatihan guna peningkatan mutu dan profesionalisme. Sarana yang mendukung membuat guru semangat bekerja, misalnya tersedianya computer disekolah membantu guru dalam menyelesaikan pekerjaan.

Selain itu, motivasi kerja guru ekonomi SMA Negeri di Kota Makassar tinggi karena sebagian besar guru bersangkutan memperoleh tunjangan sertifikasi. Hal ini sejalan dengan penelitian yang dilakukan oleh Muhammad Zulkifli, dkk (2014) yan menyatakan bahwa sertifikasi guru yaitu tunjangan profesi dengan nominal satu kali gaji pokok akan berdampak terhadap kesejahteraan guru. Selanjutnya kesejahteraan guru akan meningkatkan akan meningkatkan motivasi dan motivasi akan meningkatkan kinerja. Disisi lain hal yang dapat 
membuat guru kurang memiliki motivasi kerja misalnya: kurangnya perhatian yang diberikan kepala sekolah kepada guru yang memiliki prestasi kerja tinggi membuat guru merasa kurang dihargai atas usahanya.

Hal ini diperkuat dengan analisis yang dilakukan oleh (Tumbur Hutasoit,2011) menyatakan bahwa guru yang memiliki motivasi kerja adalah guru yang berusaha untuk bekerja lebih sungguh-sungguh karena ingin mencapai tujuan sekolah dan akan bertanggung jawab dalam tugas, perasaan senang dalam bekerja, bekerja keras, berusaha mengungguli orang lain, berusaha untuk memenuhi kebutuhan hidup, senang memperoleh pujian dan bekerja untuk memperoleh perhatian dan penghargaan.

Hasil penelitian yang dilakukan oleh Mc. Clelland, Edward Murray, Miller dan Gordon W. yang dikutip Mangkunegara (2005 : 104), menyimpulkan ada hubungan yang positif antara motivasi berprestasi dengan pencapaian kinerja/prestasi kerja. Artinya pimpinan, manajer, dan pegawai mempunyai motivasi berprestasi tinggi akan mencapai prestasi yang tinggi, dan sebaliknya mereka yang kinerjanya rendah dikarenakan motivasi kerjanya rendah.

Hasil penelitian ini bermakna, bahwa variabel motivasi mampu memberi kontribusi terhadap kinerja guru ekonomi di Kota Makassar. Oleh karena itu, semakin meningkatnya kinerja guru, maka motivasi perlu ditingkatkan melalui pemberian penghargaan atau pemberian insentif, kondisi kerja yang menyenangkan, memberi kesempatan untuk maju dan hubungan kerja yang harmonis.

\section{Pengaruh Disiplin Kerja terhadap Kinerja Guru SMA Negeri di Kota Makassar}

Berdasarkan hasil penelitian menunjukkan bahwa displin kerja memiliki pengaruh positif dan signifikan terhadap kinerja guru ekonomi SMA Negeri di Kota Makassar. Salah satu yang menyebabkan displin kerja guru ekonomi tinggi yaitu ketaatan terhadap peraturan yang merupakan sebagai wujud loyalitas seorang guru terhadap sekolah. Disiplin kerja guru ekonomi di Kota Makassar menunjukkan telah dikelola dengan baik sehingga memberikan kontribusi terhadap kinerja guru.

Temuan hasil penelitian ini sejalan dengan hasil penelitian yang dilakukan oleh Kaliri (2008) yang menyatakan menyatakan bahwa disiplin kerja berpengaruh terhadap kinerja. Hasil penelitian ini mengindikasikan bahwa disiplin kerja dapat mempengaruhi tingkat kinerja pegawai, semakin baik disiplin kerja pegawai maka akan semakin tinggi kinerja pegawai. Hal ini juga diperkuat oleh pernyataan Davis (2003 : 129) yang menyatakan disiplin kerja sebagai pelaksanaan manajemen untuk memperteguh pedoman-pedoman dipandang erat keterkaitannya dengan kinerja.

Unsur yang terikat di dalam disiplin kerja guru adalah adanya peraturan, pedoman pelaksanaan, sanksi dan hukuman, kesadaran serta kesediaan untuk mentaati dan memperteguh pedoman organisasi.Dari uraian itu bisa dijelaskan bahwa disiplin kerja merupakan salah satu bentuk kesadaran serta kesediaan pekerja untuk menghargai danpatuh, serta taat terhadap peraturan yang berlaku baik peraturan tertulis atau peraturan tidak tertulis dengan konsekuensi siap menanggung sanksi apabila melakukan kesalahan.

Kemampuan guru dalam memahami aturan dan melaksanakan aturan yang tepat, baik dalam hubungan sekolah maupun dalam proses belajar mengajar di dalam kelas. Kedisiplinan bagi seorang guru merupakan bagian yang tidak terpisahkan dalam melaksanakan tugas dan kewajiban. Hal ini sejalan dengan yang dikemukakan Fathoni (2006 : 172) bahwa disiplin kerja guru sangat diperlukan oleh seorang guru dalam melaksanakan tugasnya. Kedisiplinan merupakan kesadaran dan kesediaan seseorang mentaati semua peraturan dan norma-norma sosial yang berlaku.

Kedisiplinan guru ekonomi SMA Negeri di Kota Makassar dapat terlihat dari guru yang datang dengan tepat waktu, termasuk kedisiplinan terhadap tugas-tugas yang berlaku, seperti guru terlihat berusaha membuat RPP dan mengumpulkannya sebagai rencana pembelajaran sebelum memulai pembelajaran, meskipun tidak semua guru melakukan hal yang sama. Namun, guru saling mengingatkan terhadap tugas dan kewajiban sebagai pengajar. Kedisiplinan juga 
terlihat pada ketaatan guru yang tidak akan pulang sebelum jam pulang, meskipun tidak ada jam mengajar.

Berdasarkan hasil pengujian ini bermakna bahwa variabel disiplin kerja mampu memberi kontribusi terhadap kinerja guru ekonomi SMA Negeri di Kota Makassar. Oleh karena itu untuk semakin meningkatkan kinerja guru, maka disiplin kerja guru perlu ditingkatkan melalui kehadiran dalam kelas sebagai bentuk pelayanan minimal kepada peserta didik disekolah, dan kepala sekolah disarankan melakukan penerapan Reward dan Punishment untuk meningkatkan disiplin guru hadir didalam kelas pada kegiatan belajar mengajar disekolah.

\section{Conclusions}

Berdasarkan dari hipotesis penelitian, hasil olah data, dan pembahasan dalam penelitian ini, maka kita dapat menarik kesimpulan sebagai berikut :

1. Budaya organisasi berpengaruh positif dan signifikan terhadap kinerja guru ekonomi SMA Negeri di Kota Makassar. Hal tersebut dapat diartikan bahwa semakin tinggi budaya organisasi maka kinerja guru ekonomi SMA Negeri di Kota Makassar akan semakin meningkat.

2. Motivasi kerja berpengaruh positif dan signifikan terhadap kinerja guru ekonomi SMA Negeri di Kota Makassar. Hal tersebut dapat diartikan bahwa semakin baik motivasi kerja, maka kinerja guru ekonomi SMA Negeri Di Kota Makassar akan semakin meningkat.

3. Disiplin kerja berpengaruh positif dan signifikan terhadap kinerja guru ekonomi SMA Negeri di Kota Makassar. Hal tersebut dapat diartikan bahwa semakin baik disiplin kerja, maka kinerja guru ekonomi SMA Negeri Di Kota Makassar akan semakin meningkat

4. Berdasarkan dari hasil uji simultan kita dapat memberikan interpretasi bahwa variabelvariabel bebas yaitu variabel budaya organisasi (X1), motivasi kerja (X2), dan disiplin kerja (X3), secara simultan atau secara bersama-sama berpengaruh signifikan terhadap variabel terikat yaitu variabel kinerja guru ekonomi SMA Negeri di Kota Makassar (Y)

\section{References}

Daft, Richard. (2010) New Era Management, $9^{\text {th }}$ Edition. South Western Engage Learning.

Davis, Keith dan John W. Newstrom. 2003. Perilaku dalam Organisasi (Terjemahan Agus Darma). Jakarta: Erlangga.

Fathoni Abdurrahmat. 2006. Organisasi dan Manajemen Sumber Daya Manusia, Jakarta : PT Rineka Cipta.

Hamzah, B Uno. 2008. Teori Motivasi dan Pengukurannya. Jakarta: PT. Bumi Aksara

Hasibuan, Melayu SP.2007. Manajemen Sumber Daya Manusia Edisi Ke-9. Jakarta : Bumi Aksara

2008. Manajemen : Dasar, Pengertian dan Masalah. Edisi Revisi cetakan ketujuh.

Jakarta : Bumi Aksara

Hutasoit, Tumbur. 2011. "Pengaruh Iklim Organisasi, Kepuasan Kerja dan Motivasi Berprestasi Terhadap Kinerja Guru di SMP Negeri Kecamatan Sipoholon". Tesis. Medan: Universitas Negeri Medan

Kaliri. 2008. "Pengaruh Disiplin dan Motivasi Kerja terhadap Kinerja Guru SMA Negeri di Kabupaten Pemalang". Tesis. Semarang: Universitas Negeri Semarang

Mangkunegara, A. P. 2005. Manajemen Sumber Daya Manusia. Bandung : PT Remaja Rosdakarya. 
Indonesian Journal of Economics, Entrepreneurship and Innovation

Vol.1, No.1, Mei 2020

Available online: https:// https://journal.ilininstitute.com/IJoEEI

Ratno Nur Suryadi

Mangkuprawira, S. Hubeis A.V. 2007. Manajemen Sumber Daya Manusia, Bogor (ID) : Ghalia Indonesia.

Pabundu, Tika, 2006, Budaya Organisasi dan Peningkatan Kinerja Perusahaan, Jakarta: Cetakan Pertama, PT Bumi Aksara

Rivai, V. (2007). Kepemimpinan dan Perilaku Organisasi Ed. 2.Jakarta: Raja Grafindo Persada

Robbins, S.P, 2006. Prinsip-prinsip Prilaku Organisasi, Edisi Kelima, Jakarta : Penerbit Erlangga.

Sastrohadiwiryo, S. 2005. Manajemen Tenaga Kerja Indonesia. Jakarta: PT Bumi Aksara

Schermerhon, et a.l (2011) Organizational Behavior, Eleventh Edition. International Student Version, John Wiley \& Sons (Asia), Pte, Ltd

Sopiah. 2008, Perilaku Organisasi, CV. Andi offset, Yogyakarta.

Sudarmanto. 2014. Kinerja dan Pengembangan Kompetensi SDM (Cetakan Kedua). Yogyakarta: Pustaka Pelajar.

Zulkifli, M, dkk. 2014. Motivasi Kerja, Sertifikasi, Kesejahteraan dan Kinerja Guru. Persona Jurnal Psikologi Indonesia. Mei 2014, Vol. 3, No. 2, hal 148-155. 